\author{
Sh.S. Zhaukumova ${ }^{1}$, N.N. Khanina ${ }^{1}$, G.K. Tleuzhanova ${ }^{2}$ \\ ${ }^{I}$ Zhetysu University of the name of I. Zhansugurov, Taldykorgan, Kazakhstan \\ ${ }^{2}$ Karagandy university of the name of academician E.A. Buketov, Kazakhstan \\ (Corresponding author's E-mail: sholpan6908@mail.ru)
}

\title{
Forming communicative competence of future primary school teachers
}

\begin{abstract}
The article reveals the key stages of the formation of professional competencies of students of specialty "Pedagogy and Methodology of Primary Education" in the reform of the educational process, justifies the understanding of the term "competence", special attention is paid to various aspects of the definition of the concept. The characteristic features of global changes associated with the urgent need of society in intellectual, creative individuals with critical thinking skills are highlighted and described. In this regard, the main task of universities is the orientation of the educational process towards modernization, which consists in changing the role of the teacher, applying new approaches to the organization of the educational process, using modern educational technologies, contributing to the formation of students' competencies required in their future professional activities. The authors point out a number of topical issues related to the problem of forming professionally oriented communicative competence of future primary school teachers. The main content of the study is the analysis of the author's experience of enhancing the educational process in elementary school and the organization of conditions for the formation of professional competencies of future professionals required in the learning process, generalized educational technology, which is very relevant in the university. Based on the study of this problem conclusion was made that a renewed understanding and formation of professional and general cultural competencies of future specialists should consist not only of professional knowledge, but also general human values in general. The article presents the criteria of forming professional and communicative competences of students in higher education institution. According to the results of the study, the authors' vision of intensifying the learning process and the formation of professional competencies of students, which they need in their future profession, is presented. Pedagogical conditions contributing to the effective formation of communicative competence of a future elementary school teacher are revealed.
\end{abstract}

Keywords: primary school teacher, content of professional activities, communicative competence, specialist training, education development, professional activity, interdisciplinary integration, educational content updating, university educational process.

\section{Introduction}

In the modern period of higher education development the formation of fundamentally different specialists, whose basic characteristics include the ability for conscious personal growth, the focus on overcoming social and professional stereotypes, strengthening of professional responsibility and leadership qualities, is of particular relevance. This process is associated with the formation of educational models and technologies [1].

Preparation of students as subjects of professional and pedagogical activity remains one of the current problems, as modern Kazakhstan educational system is in a stage of dynamic renewal caused by, on the one hand, the process of reforming society as a whole, and on the other hand, the logic of the educational system development. Thus, it is important to develop new approaches, new forms of learning.

The study at the university should be communicatively oriented and professionally directed, leading to the formation of professional communicative competence.

The training at the university should be communicatively oriented and professionally directed, leading to the formation of professional communicative competence. In the studies of D. Hymes, A.V. Vakhrushev, I.A. Zimnaya, Sh.K. Zhantleuova and V.A. Slastenin the essence of communication professional and the search for optimal conditions and effective methods of formation of communicative competence of future specialists is presented. It is assumed that a successful young specialist has a number of main (research, communicative, intercultural, organizational, etc.), basic and special, in other words, professionally-oriented competencies, the formation of which, along with the acquisition of subject knowledge, constitutes the value and meaningful sphere of the participants of the educational and training process.

In psycho-pedagogical and methodological research there is a sufficient material on formation of communicative competence of students - future teachers, however in practice of higher education there is a low level of possession of the main components of communication. In this connection, pedagogical and psychological conditions of formation of this competence require clarification and thorough study. 
This competence is fundamental because it is important for the teacher to be able to establish social connections, interact with students and their parents, be able to organize cooperation, partner relations with children, have a sufficient level of development of coherent, grammatically and logically correct speech. In addition, the school teacher must have a broad outlook and the ability to explain to the students the richness of the world around them. The teacher defines and creates comfortable conditions for the democratic development of the child as an active participant in the educational process.

\section{Materials and Methods}

The content of the professional activity of primary education teachers imposes a number of specific requirements for them, forcing to develop certain personal qualities as professionally significant, necessary and obligatory. These qualities, being implemented in the teacher's activity, ensure the success of pedagogical activity, acquire a specific professional coloring, they are necessary for the performance of teacher functions (developing, informational, constructive, organizational) [2].

However, according to researchers, in particular O.I. Matyash [3] ho points out that who educational process of higher education in the course of teaching the disciplines does not pay due attention to the issue of teaching speech technique, the ability to build statements aimed at explaining, argumentative presentation of educational material. Students are not specifically taught how to coordinate communication, communicate with colleagues, administrators, parents, and most importantly with students, because the effectiveness of the educational process depends on it. In the process of communication each participant in the communicative act has their own goals and motives, the purpose of the statement.

Quite revealing is a work of I.A. Zimnaya [4] devoted to the study of the development of communicative skills in students. During the experiment it was found that teachers are not competent enough in matters of formation of communicative skills, not ready to do this work, they find it difficult to identify methods and effective techniques for raising this quality in students, not ready to accurately determine the level of development of communication skills, refer to the lack of methodological recommendations; all teachers note the importance of forming communicative skills

A.Zh. Azhibaeva's research also confirms the necessity of purposeful formation of communication skills. She states the fact that first- and second-year students of pedagogical specialties have a higher level of formation of communicative skills than university graduates, i.e., there is a decrease in these skills [5].

Analysis of the features of the educational and training process at the university showed that the problem of communicative training of future teachers of primary classes is not paid enough attention: curricula and training programs are not oriented to the formation of communicative competence in them. There is no integration with other disciplines (general education, basic) in this process, theoretical and practical aspects of psychological and pedagogical preparedness to form communicative competence are not presented enough.

Thus, a number of topical issues related to the problem of formation of professionally oriented communicative competence in future teachers of primary classes are insufficiently investigated.

We note the existence and relevance of the problem of formation of communicative competence of future teachers in the modern school based on these studies. Future teachers must have a meaningful, accurate, correct speech, ensuring successful communication and effective learning. Each teacher chooses their style of professional communication, it is important that all activities are for the benefit of the child, aimed at the harmonious personal development of the schoolchild.

Let us dwell on the characteristics of the main theoretical concepts. Competence is understood as the ability and readiness of a person to perform activities, which consist of understanding the essence of the tasks and problems to be solved, active possession of the best achievements, the ability to select ways of action adequate to the specific conditions of place and time, a sense of responsibility for the results (V.N. Vvedensky, A.A. Derkach, Sh.K. Zhantleuova, G.A. Kolesnikova, Sh. Kurmanalina, A.K. Markova, A.A. Leontiev, V.A. Slastenin, etc.). Purposeful formation of competencies allows to achieve high quality learning outcomes, increases students' independence, influences the formation of such personal qualities as purposefulness and responsibility, striving for improvement and professionalism.

One of the important professional competencies of a teacher is communicative competence, which allows to carry out effective interaction with children, and to create conditions for their cooperation with the surrounding society. A high level of communicative competence allows a teacher to optimize learning, simulate safe communication situations, broadcast adequate, flexible and variable models of communicative behavior. A teacher is required to know the techniques of verbal and nonverbal communication, to be able to 
create socio-pedagogical situations in which students practice establishing contacts with others, asking them for help and advice, building proper communication. The effectiveness of the educational process depends on the success of interpersonal interaction, the ability to enthuse in joint activities.

Modern research continues theoretical analysis of the concept of communicative competence and comprehension of this category, its substantive content is expanded. Currently, the category of communicative competence is considered widely enough, and there is still no unambiguous view on the content of this concept, on what is included in communicative competence: ability, property, body of knowledge, abilities and skills or personal qualities. Thus, the integral characteristic of a person who has the ability to solve special problems and tasks in a real situation of professional activity with the application of knowledge, experience, values and inclinations is considered through communicative competence [6].

The process of formation of the teacher includes the development of skills to establish psychological contact with students and parents, to manage the audience. Empathic qualities of the teacher are fundamental: effective love for the child, attentiveness, tolerance, generosity of soul and tactfulness. Self-development, self-control, and reflection are essential for the teacher. Subject - cognitive tasks, practice-oriented issues, personality development tasks are solved in the process of professional activity of a teacher, in the interaction of subjects of the educational process, it is possible in the organization of effective conditions of communication. The choice and relevance of the topic of research is determined by a number of factors, such as the social order of society to graduate qualified specialists with professional competence, lack of theoretical and practical development ensuring full-fledged communication in various spheres of activity.

The purpose of this study is to form the professional competence of the future elementary school teacher.

The following tasks were solved in carrying out the study:

- to reveal the content of the definition of communicative competence and to highlight its structure;

- to characterize the main pedagogical aspects on the development of communicative competence of a primary education specialist;

- to clarify the content, the essence of the place and role of communicative-speech competence, to structure the model of professional training of an elementary school teacher.

\section{Results and Discussion}

The following tasks for the first phase of the study were defined. The experiment was organized in three stages.

At the first (primary) stage the methodological aspects of the study were considered, the theoretical directions of psychological and pedagogical literature were studied. Then the diagnostics of the level of formation of communicative skills in the students of the specialty "Pedagogy and Methodology of Primary Education" in the experimental and control groups was carried out.For this purpose diagnostic materials and tests were selected, and questionnaire questions were developed. In the ascertaining experiment the methods of diagnostics of V.V. Sinyavsky and B.A. Fedorishin [6] were used, determining the level of sociability by the method of Y.M. Zhukova [7].

The research was based on the educational process of the Faculty of Pedagogy and Psychology of Zhetysu University named after Ilyas Zhansugurov, students of 1-2 years were involved.

Also as methods of diagnostics we chose interview with students, conversations with teachers, expert assessment, self-diagnosis, performance of tasks, results of tests and examinations, the analysis of creative works on methodological disciplines aimed at performance of labor activity.

Analyzing the data of the ascertaining experiment, we can highlight that teachers and students note the relevance of the problem of formation of communicative skills. At the same time they point to the current low level of development of communicative skills. Students find it difficult to accurately express the communicative task, choose the right word and phrase in this pedagogical situation, violate the norms of literary pronunciation of words, which leads to slang colloquial speech, make mistakes in the style of the statement. It is difficult to establish contact with the child. Future teachers believe that they need communicative, organizational, and didactic abilities to a greater extent in their work activity, because they see the profession of a teacher first of all as a communicational, organizational, and educational activity.

We conducted a questionnaire survey, a conversation, the purpose of which was to identify the reasons for choosing the profession of elementary school teacher, the presence or absence of interest in this activity, understanding, as well as identifying students' satisfaction with the quality of professional training in higher education and their professional intentions in the future. Students were offered questionnaires to study the their current level of motivation and personality component, as well as the state of the pedagogical process [8]. 
Having analyzed the state of formation of motivational and personal component in students of the specialty "Pedagogy and Methodology of Elementary Education", we concluded that this component is formed at the low and the average level. The least represented is the presence of students' awareness of communication as the basis of their activities, hence students have no desire, and therefore the need, to improve the necessary communicative knowledge, skills and methods of communication, as well as personal qualities in this area. At the same time, students expressed a lack of satisfaction with their readiness to enter the teaching profession, uncertainty about their future employability, and anxiety about interaction with members of the school staff and their ability to work with students' parents.

The study of L.A. Povarnitsina [9] gives reasons why students have difficulties in the implementation of communicative skills. So, to the question "What do you understand by the object of your future profession" $52 \%$ of students named teaching children to read and write, $30 \%$ teach children to read, write, count, $10 \%$ of students did not answer at all, and only $8 \%$ of students pointed to the educational process. The interviewees did not adequately define the activity of an elementary school teacher. Students also had difficulty naming all the regularities of the educational process in school, which indicates a low level of theoretical knowledge and the unlikelihood of effective application of the acquired skills in practice [9].

Thus, the analysis of the results of the study of the formation of the content component of communicative competence of future elementary school teachers indicates the poor development of knowledge about the object of professional activity, insufficient understanding of the varieties of communication (monological and dialogic, speech and nonverbal, business and personal) and the requirements for their implementation.

During the evaluation of senior students (3-4 year, 53 students) of the Faculty of Pedagogy and Psychology, students were asked questions about the use of interactive dialogical forms of learning by teachers in the process of teaching major disciplines. The data are as follows:

Difficulty to communicate with students, fellow students - $40 \%$;

Can not organize a dialogue $-25 \%$;

Do not know the technology of dialogical learning - $35 \%$.

During the conversation the question was asked: "Did you learn communication skills during your studies at the university, if so, in what form?" Students pointed to practical classes in such disciplines as "Methods of teaching the Russian language", "Methods of teaching English" during which individual speech and communication skills were practiced. As can be seen, there is only a language orientation and a lack of consistency and inter subject in this process.

Students who do not have sufficiently developed communication skills are characterized by inability to convey their own thoughts to others and formulate answers to questions addressed to them, they also do not know how to formulate their own questions. There are students who simply shut down, and the discomfort manifests itself at the level of physiological manifestations: redness of the skin, anxiety, embarrassment or detachment.

During the discussion they often show incorrect behavior. They cannot reasonably defend their own position and flexibly change it. When interacting in a group, they do not obey the general decision. With them, it is necessary to use methods of work aimed at organizing the discussion, direct it in the right direction, while not suppressing anyone's opinion, but giving the opportunity to speak out, justify, just voice the idea. In any case, critical remarks, irony, or distrust about the answer expressed or the example given should not be allowed. An important rule - every opinion is valuable, this is the first step for establishing contact with classmates, a teacher.

Students in the middle group show difficulties in reacting to problematic situations, answering questions addressed to them, show excitement or cannot find the right phrases. Students of the average group often cannot convince their opponents, sometimes do not obey the decision of the group without an explanation and the rules of it, enter conflict situations, preventing the group from finding the solution of the general problem. With these students it is important to practice social networking skills, learn to listen to and respect the opinions of others, develop reflection, the ability to see yourself from the outside. It is desirable to help in the development of asserting one's position or intelligently changing it, defend their position in an argument, change it reasonably, and comply with the decision of the group for the success of the common cause, work to improve the ability to articulate one's thoughts with students in this group, formulate questions to the interlocutor, and answer the questions posed.

Strong group of students is able to reason their position clearly and understandably for all participants in the process of communication, give exhaustive answers to questions, change their opinion if necessary, be able to obey the decision of the group to achieve the goal. 
Initial levels of communicative competence formation among students of the specialty "Pedagogy and Methodology of Primary education" are shown in the table 1.

$\mathrm{Tab} 1 \mathrm{e} 1$

Initial levels of formation of communicative competence among students of the specialty "Pedagogy and methodology of primary education" (PMPE) in (\%)

\begin{tabular}{|c|c|c|c|c|}
\hline \multirow[b]{2}{*}{$\begin{array}{l}\text { Level of the formation } \\
\text { of communicative competence (CC) }\end{array}$} & \multicolumn{4}{|c|}{ Number of students (in \%) having CC } \\
\hline & $\begin{array}{l}\text { Motivational } \\
\text { and personal }\end{array}$ & Informative & Practical & $\begin{array}{l}\text { Psychological } \\
\text { and ethical }\end{array}$ \\
\hline Low & 73,2 & 73,7 & 72,3 & 55,8 \\
\hline Average & 26,8 & 26,3 & 27,7 & 44,2 \\
\hline Necessary & - & - & - & \\
\hline High & - & - & - & \\
\hline
\end{tabular}

In order to identify the overall level of formation of communicative competence of future elementary school teachers we identified four criteria (P1, P2, P3, P4) characterizing the state of communicative competence, which correlated with the level of formation, i.e. their qualitative description: low, medium, necessary and high.

The presence of low and average levels of students does not contribute to quick adaptation, and, consequently, successful professional activity. Changes in the results of training will be explained by the introduction in the educational process of various pedagogical conditions that contribute to the formation of this integral an quality in future elementary school teachers. In the presence of disciplines of communicative nature, communicative knowledge and skills are presented superficially, fragmentarily and haphazardly. Many students had difficulties in defining the basic concepts of communication theory, in determining the role and specificity of communication, communicating their professional activities. Despite the humanitarian orientation of this specialty, very clearly there is a lack of purposeful fundamental communicative training focused on the development of communicative competence in students.

Thus, the results of the ascertaining experiment indicated a predominantly low level of formation of communicative competence, which actualizes the organization and conduct of experimental and pedagogical work on the formation of this quality in students to test the effectiveness of the proposed research system and methodology, as well as testing the identified teaching conditions in the holistic teaching process of the university. Almost all the disciplines of the humanities, psychological and pedagogical cycle have possibilities for the formation of communicative competence as of affect and the various aspects of communication within their subject areas, as well as special disciplines that prepare for direct professional activities, the purpose of which dictates the purpose of communication; and pedagogical practice, allowing to consolidate the knowledge and skills in a real activity. But they do not solve the independent task of forming the communicative competence of future teachers.

As we have already noted, future teachers are not taught enough pedagogical communication. And the problem of formation of communicative skills in general falls out of the educational process at the university. Hence the contradiction in the professional formation of the future teacher: having knowledge, the teacher is poorly armed with the technique of its effective transfer.

At the formative stage this stage forms and methods of formation of professional abilities of future teachers of primary classes in higher education institutions are theoretically justified the model of development of professional communicative competences of students - future teachers of elementary school during training in higher education institution based on formation of investigated competences is offered, the pedagogical conditions providing efficiency of this process are experimentally tested. The intermediate results are tracked.

When organizing a holistic pedagogical process attention was paid to the types of activities, forms, methods and techniques, assignments, i.e. means providing the movement and development of the pedagogical process for the formation of communicative competence in students of the Faculty of Pedagogy and Psychology. The communicative activity of future elementary school teachers, in our opinion, should be the basis when organizing the pedagogical process throughout the course of students' training by including them in such activities as learning and cognitive, research, labor (internship), communication, play. 
Of particular interest for our study is pedagogical design, which is understood as a preliminary development of the main details of the upcoming activities of students and teachers, i.e. creating a presumptive version of the upcoming activities and predicting its result. The objects of pedagogical design can be pedagogical systems, pedagogical process, pedagogical situations. In our case the pedagogical process, namely the process of formation of communicative competence of students of PMPE specialty, is the object of design.

Pedagogical design is characterized as a complex multi-step activity consisting of three consecutive stages (or steps) which allow to bring "the development of the forthcoming activity from a general goal to precisely described concrete actions":

- Modeling (creation of the model, that is, the development of objectives or the overall goal of creating the process of formation of communicative competence of teachers).

- Designing (creation of the project, further development of the created model and bringing it to the level of practical use).

- Designing (creation of the construct, namely further detailing of the created project, approaching it for use in specific conditions by real participants of pedagogical process of higher education institution).

\section{Conclusions}

The above-mentioned allows stating that pedagogical design begins with the creation of a model that allows predicting the process of formation of communicative competence of future teachers. At the second stage the work with the created model, which can be used directly to transform any pedagogical reality, in particular the process of formation of communicative competence in students, is made. Then the third stage further details the project, specifies it and brings it closer to the real conditions of activity.

We believe that this stage to a greater extent is decisive, because if the student has formed a positive motivation for the chosen profession and its basis, which is communication, then there are favorable conditions for the quality to be formed.

Communicative and verbal competence of an elementary school teacher is one of the significant components of his professional competence determining the culture of interaction in the process of conducting pedagogical activity. It is an integral, developing quality of a specialist who possesses the knowledge of the basics of the process of educational communication, abilities, skills and techniques of communication, reflection able to comunicate, a variety of statements in both oral and written form.

Thus, we identified the pedagogical conditions that contribute to the effective formation of communicative competence of a future teacher, which include the implementation of the relationship of academic disciplines in the formation of communicative competence; use of active learning methods in the educational process of higher education; use of variable courses in the formation of communicative competence of the future teacher, implementation of activity-based approach in the communicative-oriented practice.

\section{References}

1 Государственная программа развития образования и науки Республики Казахстан на 2016-2019 годы [Электронный ресурс]// Әділет. Информационно-правовая система нормативных правовых актов Республики Казахстан. — Астана, 2016. - Режим доступа: http://adilet.zan.kz/rus/docs/U1600000205.

2 Ковалева Г.Н. Формирование коммуникативной компетентности у студентов вузов культуры и искусств в процессе интегрированного обучения риторике и этикету: дис. / Г.Н. Ковалева. — М. 2006. — 213 с.

3 Матьяш О.И. Что такое коммуникация и нужно ли нам коммуникативное образование? / О.И.Матьяш // Сибирь. Философия. Образование. - 2002. — № 6. - С. 36-47.

4 Зимняя И.А. Общая культура и социально-профессиональная компетентность человека / И.А. Зимняя // Высшее образование сегодня. — 2005. - № 11. - С. 14-20.

5 Ажибаева А.Ж. Реализация личностно-ориентированного подхода в профессиональном воспитании будущего учителя: автореф. ... канд. пед. наук / А.Ж. Ажибаева. — Бишкек, 2007. — 22 с.

6 Коммуникативные и организаторские склонности. В.В. Синявский, В.А. Федорошин (КОС) [Электронный ресурс]. — Режим доступа: http://testoteka.narod.ru/lichn/1/17.html

7 Жукова Ю.М. Диагностика и развитие коммуникативной компетентности: учеб. пос. / Ю.М. Жукова, Л.А. Петровска, П.В. Растянникова. - М.: Изд-во Моск. ун-та, 1991. - 96 с.

8 Бухарова И.С. Психология. Практикум: учеб. пос. для бакалавриата и специалитета / И.С. Бухарова, М.В. Бывшева, Е.А. Царегородцева. — 2-е изд., перераб. и доп. - М.: Юрайт, 2019. — 208 с.

9 Поварницына Л.А.Психология личности вузовского преподавателя: учеб. пос. / Л.А.Поварницына. — Тверь: Изд-во ТГУ, 1995. - 99 с. 


\title{
Ш.С. Жаукумова, Н.Н. Ханина, Г.К. Тлеужанова \\ Болашақ бастауыш сынып мұғалімдерінің коммуникативтік кұзыреттілігін қалыптастыру
}

\begin{abstract}
Мақалада білім беру процесін реформалауда «Бастауыш білім беру педагогикасы мен әдістемесі» мамандығы студенттерінің кәсіби құзыреттілігін қалыптастырудың негізгі кезеңдері ашылған, «құзыреттілік» терминін түсіну негізделген, осы ұғымды анықтаудың әртүрлі аспектілеріне ерекше назар аударылған. Авторлар болашақ бастауыш сынып мұғалімдерінің кәсіби-бағдарланған коммуникативтік құзыреттілігін қалыптастыру мәселесіне байланысты бірқатар өзекті мәселелерді анықтаған. Мақалада студенттердің жоғары оқу орындарында кәсіби және коммуникативтік құзыреттілігін қалыптастыру критерийлері көрсетілген. Зерттеу нәтижелері бойынша оку процесін қарқындату және студенттердің болашақ мамандығына қажетті кәсіби құзыреттіліктерін қалыптастыру туралы авторлық көзқарас ұсынылған. Болашақ бастауыш мектеп мұғалімінің коммуникативтік құзыреттілігін тиімді қалыптастыруға ықпал ететін педагогикалық жағдайлар анықталды. Сонымен қатар жоғары білім берудегі кәсіби коммуникативтік құзыреттілікті дамытудың практикалық механизмін көрсететін оқытудың педагогикалық тәжірибесі ұсынылған.
\end{abstract}

Кілт сөздер: бастауыш сынып мұғалімі, кәсіби қызметтің мазмұны, коммуникативтік құзыреттілік, маман даярлау, білім беруді дамыту, кәсіби қызмет, пәнаралық интеграция, білім беру мазмұнын жаңарту, жоғары білім беру.

\section{Ш.С. Жаукумова, Н.Н. Ханина, Г.К. Тлеужанова \\ Формирование коммуникативной компетенции будущих учителей начальных классов}

\begin{abstract}
В статье раскрыты ключевые этапы формирования профессиональных компетенций учащихся специальности «Педагогика и методика начального образования» в реформировании образовательного процесса, обосновано понимание термина «компетенция», особое внимание уделено различным аспектам определения этого понятия. Авторами представлены критерии формирования профессиональных и коммуникативных компетенций студентов в вузе. По результатам исследования представлено авторское видение интенсификации учебного процесса и формирования профессиональных компетенций студентов, необходимых им в будущей профессии. Выявлены педагогические условия, способствующие эффективному формированию коммуникативных компетенций будущего учителя начальной школы. Кроме того, представлен педагогический опыт обучения, отражающий практический механизм развития профессиональной коммуникативной компетентности в высшем образовании.
\end{abstract}

Ключевые слова: учитель начальных классов, содержание профессиональной деятельности, коммуникативная компетентность, подготовка специалиста, развитие образования, профессиональная деятельность, межпредметная интеграция, обновление содержания образования, учебный процесс вуза.

\section{References}

1 Gosudarstvennaia programma razvitiia obrazovaniia i nauki Respubliki Kazakhstan na 2016-2019 gody. Adilet. Informatsionno-pravovaia sistema normativnykh pravovykh aktov Respubliki Kazakhstan [State program of education development and science in the Republic of Kazakhstan for 2016-2019. Adilet. Information and legal system of normative legal acts of the Republic of Kazakhstan]. (2016). Astana.adilet.zan.kz. Retrieved from http://adilet.zan.kz/rus/docs/U1600000205 [in Russian].

2 Kovaleva, G.N. (2006). Formirovanie kommunikativnoi kompetentnosti u studentov vuzov kultury i iskusstv v protzesse integrirovannogo obucheniia ritorike $\mathrm{i}$ etiketu [Formation of communicative competence among students of universities of culture and arts in the process of integrated training in rhetoric and etiquette]. Candidate's thesis. Moscow [in Russian].

3 Matyash, O.I. (2002). Chto takoe kommunikatsiia i nuzhno li nam kommunikativnoe obrazovanie? [What is communication and do we need communication education]. Sibir. Filosofiia. Obrazovanie - Siberia. Philosophy. Education, 6, 36-47 [in Russian].

4 Zimnyaya, I.A. (2005). Obshchaia kultura i sotszialno-professionalnaia kompetentnost cheloveka [General Culture and Socio-Professional Competence of Man]. Vysshee obrazovanie segodnia - Higher Education Today, 11, 14-20 [in Russian].

5 Azhibaeva, A.Zh. (2007). Realizatsiia lichnostno-orientirovannogo podkhoda v professionalnom vospitanii budushchego uchitelia [Implementation of a personality-oriented approach in the professional education of a future teacher]. Extended abstract of candidate's thesis. Bishkek [in Russian].

6 Kommunikativnye i orhanizatorskie sklonnosti. V.V. Sinyavskii, V.A. Fedoroshin (KOS) [Communicative and Organizational Aptitudes V.V. Sinyavsky, V.A. Fedoroshin]. testoteka.narod.ru. Retrieved from http://testoteka.narod.ru/lichn/1/17.html [in Russian].

7 Zhukova, Yu.M., Petrovska, L.A., \& Rastyannikova, P.V. (1991). Diagnostika i razvitie kommunikativnoi kompetentnosti [Diagnosis and development of communicative competence]. Moscow: Izdatelstvo Moskovskogo universiteta [in Russian]. 
8 Bukharova, I.S., Byvsheva, M.V., \& Tsaregorodtseva, E.A. (2019). Psikhologiia. Praktikum [Psychology. Workbook for Bachelor's and Specialist's Degree]. Moscow: Izdatelstvo «Yurait» [in Russian].

9 Povarniczyna, L.A. (1995). Psikhologiia lichnosti vuzovskogo prepodavatelia [Psychology of the personality of the university teacher]. Tver: Izdatelstvo Tverskogo gosudarstvennogo universiteta [in Russian]. 